\title{
Bacterial growth rates and productivity within a seagrass system: seasonal variations in a Posidonia oceanica bed
}

\author{
Branko Velimirov, Martha Walenta-Simon*
}

Institut für Allgemeine Biologie, Universität Wien, Schwarzspanierstr. 17, A-1090 Wien, Austria

\begin{abstract}
Bacterial growth rates and production were determined for the bacterial community in the water layer within a seagrass meadow of Posidonia oceanica at a permanent station in $20 \mathrm{~m}$ depth in the Bay of Calvi (west coast of Corsica). Over summer 1989 and winter 1990 there were only small variations in numbers of bacteria, decreasing by a factor of 2 from summer to winter. Significant variations in cell number were observed in summer 1990 where values ranged from 3.6 to $19.4 \times 10^{5}$ cells $\mathrm{ml}^{-1}$. Differences in bacterial biomass were more pronounced over the seasons and primarily determined by changes in abundance and biovolume of rod-shaped bacteria with a minimum of $6.8 \mu \mathrm{g} \mathrm{C} \mathrm{l}^{-1}$ in winter and a maximum of $81 \mu \mathrm{g} \mathrm{C} \mathrm{l}^{-1}$ for summer 1990. Bacterial growth rates, obtained from in situ dialysis bag incubations of $2 \mu \mathrm{m}$ prefiltered seawater sampled within the meadow, were at their maximum in summer $(0.058$ and $0.074 \mathrm{~h}^{-1}$ for 1989 and 1990 respectively) and showed no correlation with chlorophyll a concentrations monitored within the meadow, which had their maximum in winter when specific growth rates were below $0.002 \mathrm{~h}^{-1}$ Doubling times $(g)$ varied between 12.8 and $36.2 \mathrm{~h}$ from July to September but between 108.3 and $409.3 \mathrm{~h}$ from January to April. The estimated bacterial carbon production rates, amounting to 0.02 to $1.72 \mu \mathrm{g} \mathrm{Cl}^{-1}$ $\mathrm{h}^{-1}$ in winter and 0.50 to $6.67 \mu \mathrm{g} \mathrm{Cl}^{-1} \mathrm{~h}^{-1}$ in summer, were not significantly different to the rates obtained from the water column above the meadow during the same sampling period. The carbon requirements of the bacteria within the meadow are discussed and related to the available data on primary production and carbon release from previous studies achieved in the Bay of Calvi and on $P$. oceanica systems from ather sites in the Mediterranean Sea.
\end{abstract}

Since 1985, the Bay of Calvi (west coast of Corsica) has been the subject of a research program designed to understand and quantify the carbon and energy flow in the water column and the benthic community. The water body of the bay is influenced by mixing and exchange processes due to seasonal coastal currents and changing wind regimes; the benthic ecosystem is dominated by a dense seagrass bed of Posidonia oceanica extending from 4 to $35 \mathrm{~m}$ depth.

\footnotetext{
- Present address: Bundesanstalt für Wassergüte, Schiffmühlstr. 120, A-1223 Wien, Austria
}

Although import of easily degradable POC and DOC of planktonic origin into the meadow and export of refractory POC into the water column is expected to take place (Velimirov et al. 1981, Velimirov 1987), the microbial compartments of the water column and of the meadow were investigated separately. Adult Posidonia oceanica leaves are known to grow up to $1 \mathrm{~m}$ length and tend to bend over, thus forming a canopy which shades off the younger leaves of the meadow. Where the density of the seagrass shoots is high and uniform the canopy forms a plant boundary, which seems to separate a faunal community within the meadow from the rest of the water column. A typical seagrass fauna associated with $P$. oceanica has been described by Harmelin (1964) and Ledoyer (1966). We hypothesized that the heterotrophic bacteria population in the water within the meadow, being close to the sediment, to a specific seagrass fauna and to dead leaves in various stages of degradation (i.e. wrack beds), may have different specific growth rates and/or production values than the bacteria in the rest of the water column.

In a previous study (Velimirov \& Walenta-Simon 1992) we reported on seasonal variations in growth rates, production and biomass of the bacterial community in the water body above the seagrass system. The present study deals with the seasonal growth dynamics of the bacterial community in the water layer within the seagrass meadow. Similar to the earlier report, growth of the bacterial population was determined by direct observation using in situ incubations in dialysis bags. The obtained biomass and production values complemented the available data from our previous study, leading to a better description of the bacterial dynamics in the water of a Mediterranean seagrass system on a seasonal basis.

The investigation site was a permanent station marked by a surface buoy, situated $300 \mathrm{~m}$ off the 
research station STARESO in the Bay of Calvi (Punta Revellata). All measurements, water sampling and in situ incubations took place at $20 \mathrm{~m}$ depth and in close proximity to the sites where we monitored growth rates of the bacterial population in the water column at 3 different depths (Velimirov \& Walenta-Simon 1992).

Temperature was measured at least 4 times a month as well as at the start and end of each incubation experiment by SCUBA divers. Water samples for the determination of bacterial numbers, incubation experiments and chlorophyll $a$ (chl a) measurements were collected between June 1989 and July 1990 by SCUBA divers using several 1.0 l PVC syringes fitted with tubes ( $30 \mathrm{~cm}$ length, $1.5 \mathrm{~cm}$ diameter) which could be introduced between the leaves, thus minimizing mixing between the 2 water bodies. All sampling gear and containers were acid-washed and rinsed with distilled water prior to use. Glassware used for pooling water samples taken from within the meadow was autoclaved after being cleaned as described above. To determine bacterial secondary production, the pooled water samples were taken to the laboratory and processed as described in Velimirov \& Walenta-Simon (1992). In brief, the water was $2 \mu \mathrm{m}$ gravity filtered to eliminate the majority of the bacterial predators, split into $1.2 \mathrm{l}$ subsamples and poured into separate, pretreated dialysis bags (Union Carbide, $65 \mathrm{~mm}$ inflated diameter, molecular weight cutoff 12000 to $14000 \mathrm{Da}$ ). Pretreatment of the bags is described in Velimirov \& Walenta-Simon (1992) and Turley \& Lochte (1985). Three $20 \mathrm{ml}$ aliquots were immediately sampled from the bags and preserved with $800 \mu$ l of $35 \%$ formaldehyde each to determine bacterial abundance at the beginning $\left(t_{0}\right)$ of the incubation experiment. SCUBA divers positioned the dialysis bags in pairs or triplicates within the meadow, keeping the bags in upright positions by connecting one end of the bag with a polypropylene rope $t_{0}$ a bottom weight and the other end to a small buoy. Care was taken to keep the bags above the sandy bottom but below the leaf canopy. Sample treatment and deployment of the bags was achieved within $55 \mathrm{~min}$, using a light-tight cooling box for the transport of the bags on the boat, and all bags were collected $24 \mathrm{~h}$ after immersion. After transport to the laboratory ( $5 \mathrm{~min}$ ) three $20 \mathrm{ml}$ aliquots were taken from each bag $\left(t_{1}\right)$ for replicate bacterial counts, using AODC technique (Hobbie et al. 1977) with a Leitz Diaplan microscope fitted with a Leitz Orthomat E Photosystem. If samples were not counted within $48 \mathrm{~h}$ they were stored at 2 to $4{ }^{\circ} \mathrm{C}$ in the dark. All samples were processed and counted within $24 \mathrm{~d}$. Bacterial growth rate was calculated by the equation for exponential growth: $\mu=\left(\ln N_{1}-\ln N_{0}\right) /\left(t_{1}-t_{0}\right)$ where $N_{0}$ and $N_{1}=$ bacterial abundance at the beginning and end of an incubation interval; $t_{0}$ and $t_{1}=$ beginning and end- ing incubation times. The doubling time was calculated as $g=\ln 2 / \mu$. Bacteria were sized by eyepiece micrometer and our size estimates controlled with both an automatic image analyser (Leitz-ASBA III) and a semi-automatic image analyzer (Leitz-ASM 68K) on magnifications of epifluorescence photomicrographs (Lee \& Fuhrman 1987) using fluorescent latex beads of known diameter (Polyscience Lim.) for calibration. We counted all cells in 30 fields per aliquot and sized between 150 to 180 cells per aliquot, classifying bacteria into cocci, rods, curved rods and spirillae (Velimirov \& Walenta-Simon 1992). The frequency of dividing cells was determined by the method of Hagström et al. (1979), and cellular carbon was calculated according to

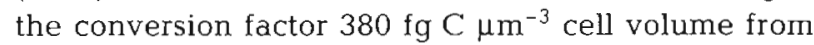
Lee \& Fuhrman (1987). Chl a was determined according to Parsons et al. (1985). Phytoplanktonic primary production estimates in the water within the meadow were obtained by incubating capacity calibrated light and dark Winkler flasks placed upright on the bottom between the seagrass shoots. We incubated 4 to $6 \mathrm{~h}$ between 09:30 and 17:00 $\mathrm{h}$ and monitored the evolution of dissolved oxygen according to the modified Winkler procedure (Parsons et al. 1985), using a Metrohm titration system consisting of a digital Titroprocessor 686 and a Multidosimat (Dosimat 665) with automatic burette and digital display combined with a platinum electrode (Velimirov \& Walenta-Simon 1992). We used a photosynthetic quotient of 1.36 (Williams \& Robertson 1991) and a respiratory quotient of 1.0 (Holligan et al. 1984, Bender et al. 1987) to convert $\mathrm{O}_{2}$ values into carbon equivalents.

Bacterial numbers within the meadow ranged from 3.66 to $19.48 \times 10^{5}$ cells ml $^{-1}$ between 1989 and 1990 (Fig. 1), both values being recorded in summer 1990 . The seasonal abundance pattern of rod-shaped bacteria followed the variation pattern of the total cell numbers but their abundance remained generally below $50 \%$ of the total counts, with the exception of the early and late summer samples from 1990. In all other samples, cocci and curved rods were the dominant bacteria morphotypes. The frequency of dividing cells ranged from 0.8 to $4.4 \%$ and within the seasons $\%$ FDC values decreased when cell numbers increased and vice versa. Bacterial biomass estimates (Fig. 2) varied between 6.8 and $81 \mu \mathrm{g} \mathrm{Cl}^{-1}$ over the 2 years. The lowest values were recorded in September 1989 and January 1990, the highest value was noted in July 1990. Although rod-shaped bacteria were numerically less important than the other bacteria morphotypes in most of the samples, their biomass contribution was higher than for the other morphotypes over the 2 years, varying between 40 and $86 \%$ of the total biomass.

The seasonal variation pattern of specific bacterial growth rates estimated from dialysis bag experiments 

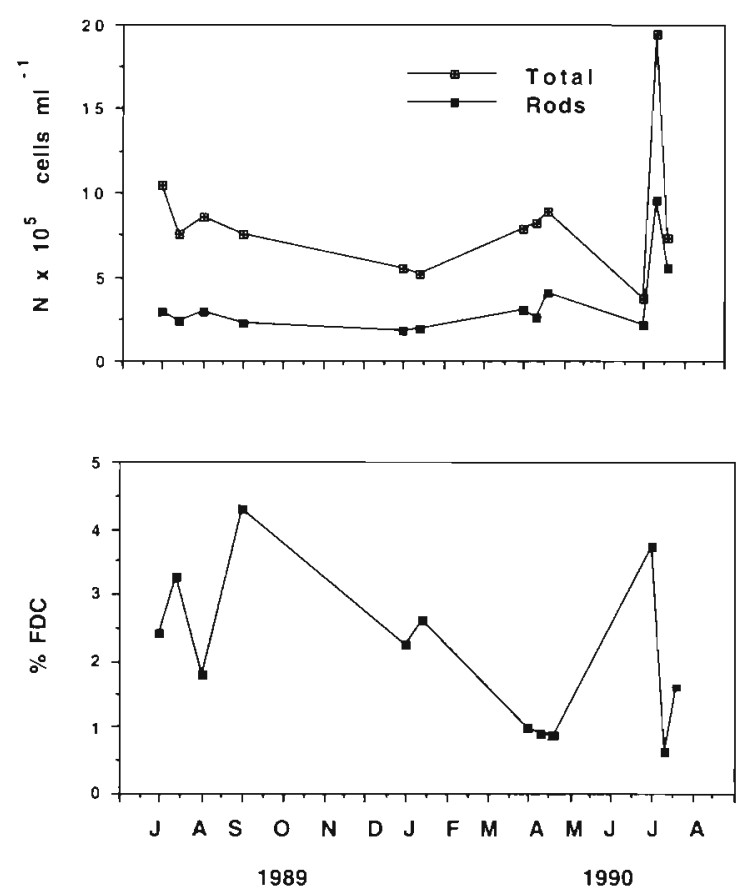

Fig. 1. Variations in total number and rod-shaped bacteria and frequency of dividing cells in the water layer within a Posidonia oceanica meadow at $20 \mathrm{~m}$ depth from 1989 to 1990 . Each value is the mean of 2 samples, each sample being subsampled twice

(Fig. 3) was more pronounced than variations in number and biomass within the meadow. High specific growth rates occurred in summer $1989\left(0.058 \mathrm{~h}^{-1}\right)$ and summer $1990\left(0.074 \mathrm{~h}^{-1}\right)$. During winter and early spring the calculated specific growth rates decreased below $0.01 \mathrm{~h}^{-1}$. The variation pattern of the specific growth rates increased and decreased with temperature within the meadow and did not follow the variations of chl a concentrations within the meadow and over the seasons, showing a maximum in winter $\left(0.37 \mu \mathrm{g} \mathrm{l}^{-1}\right)$ and minimum values in summer $\left(0.011 \mu \mathrm{g} \mathrm{l}^{-1}\right)$. With the exception of the peak in winter,

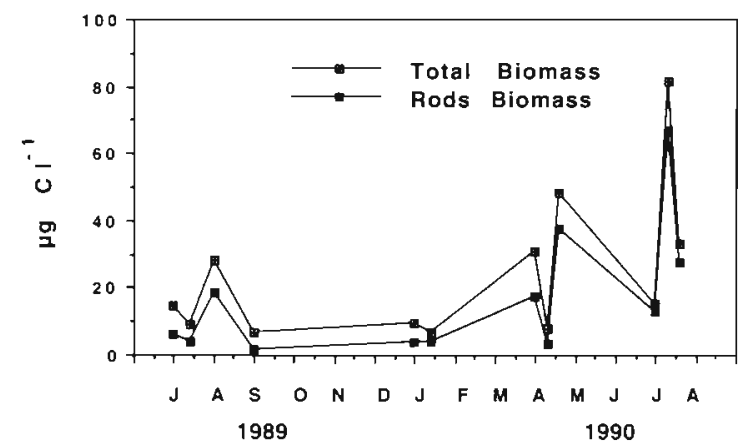

Fig. 2. Changes in bacterial biomass in the water layer within a Posidonia oceanica meadow at $20 \mathrm{~m}$ depth from 1989 to 1990
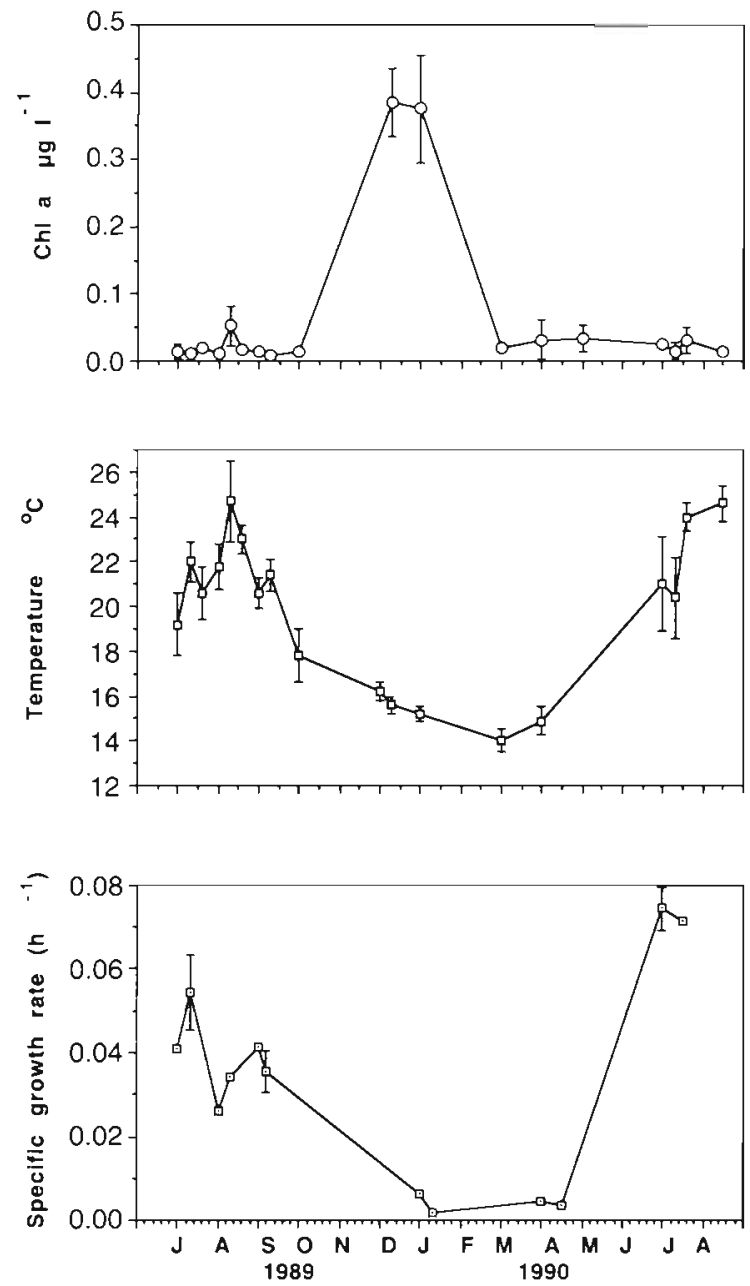

Fig. 3. Variations in chlorophyll a, temperature and specific growth rate of bacteria (mean $\pm \mathrm{SD}$ ) in the water layer within a Posidonia oceanica meadow at $20 \mathrm{~m}$ depth from 1989 to 1990

the chl a concentrations within the meadow were low and varied between 0.011 and $0.038 \mu \mathrm{g} \mathrm{l}^{-1}$ over the rest of the year.

In Table 1 we show our estimates of a number of growth parameters of the $2 \mu \mathrm{m}$ filtered bacterial population from dialysis bag experiments. Mean generation time for summer 1989 and 1990 was $20.10 \mathrm{~h}$ $(\mathrm{SD}=8.03$ ), ranging from 11.5 to $36.2 \mathrm{~h}$. For winter and early spring the mean generation time was $221.3 \mathrm{~h}$ $(\mathrm{SD}=132.2$ ) or $9.2 \mathrm{~d}$ and ranged from 108.3 to $409.3 \mathrm{~h}$. Significant differences were recorded for the magnitude of FDC values over the incubation time. FDC values obtained at the begin of the incubation $\left(t_{0}\right)$ varied from 1.0 to $5.3 \%$ over the seasons and were similar to the frequencies recorded in the samples used for number (Fig. 1) and biomass estimations. FDC values after $24 \mathrm{~h}\left(t_{1}\right)$ had always increased, and ranged from 1.28 to $37.1 \%$ over the year. The statistical comparison of \%FDC values before and after the 
Table 1. Generation time $(g, h)$ i frequency of dividing cells $(\% F D C)$ at the beginning of the incubation $\left(t_{0}\right)$ and after $24 \mathrm{~h}\left(t_{1}\right)_{i}$ standing stocks (biomass); and production of bacterial populations in $2 \mu \mathrm{m}$ filtered water from within the meadow in $20 \mathrm{~m}$ depth in the Bay of Calvi (Corsica). Values are means of the dialysis bag incubations (n) per day

\begin{tabular}{|c|c|c|c|c|c|c|}
\hline \multirow[t]{2}{*}{ Date } & & \multirow[t]{2}{*}{$g$} & \multicolumn{2}{|c|}{ FDC $(\%)$} & \multirow{2}{*}{$\begin{array}{c}\text { Biomass } \\
\left(\mu \mathrm{C} \mathrm{Cl}^{-1}\right)\end{array}$} & \multirow{2}{*}{$\begin{array}{l}\text { Production } \\
\left(\mu g C I^{-1} h^{-1}\right)\end{array}$} \\
\hline & & & $t_{0}$ & $t_{1}$ & & \\
\hline \multicolumn{7}{|l|}{1989} \\
\hline $6-7 \mathrm{Jul}$ & $\mathrm{n}=2$ & 16.96 & 2.95 & 37.10 & 15.80 & 2.94 \\
\hline $15-16 \mathrm{Jul}$ & $\mathrm{n}=3$ & 12.80 & 2.01 & 29.10 & 14.20 & 1.21 \\
\hline 2-3 Aug & $\mathrm{n}=2$ & 26.60 & 4.78 & 21.25 & 13.77 & 0.81 \\
\hline 16-17 Aug & $\mathrm{n}=2$ & 20.42 & 5.30 & 20.35 & 14.60 & 0.50 \\
\hline 7-8 Sep & $\mathrm{n}=2$ & 16.78 & 3.52 & 9.67 & 8.26 & 1.76 \\
\hline 23-24 Sep & $\mathrm{n}=3$ & 19.52 & 4.70 & 6.54 & 9.00 & 1.14 \\
\hline \multicolumn{7}{|l|}{1990} \\
\hline $20-21$ Jan & $\mathrm{n}=1$ & 108.38 & 1.18 & 3.87 & 9.45 & 0.29 \\
\hline $28-29$ Jan & $\mathrm{n}=2$ & 409.36 & 1.00 & 1.28 & 8.79 & 0.02 \\
\hline 13-14 Apr & $\mathrm{n}=2$ & 156.26 & 2.43 & 7.45 & 9.12 & 1.72 \\
\hline $16-17 \mathrm{Apr}$ & $\mathrm{n}=2$ & 211.56 & 2.55 & 5.84 & 17.84 & 1.03 \\
\hline $7-8 \mathrm{Jul}$ & $\mathrm{n}=3$ & 36.28 & 3.03 & 12.87 & 38.37 & 1.25 \\
\hline $18-19 \mathrm{Jul}$ & $\mathrm{n}=2$ & 11.51 & 2.41 & 12.32 & 47.51 & 6.67 \\
\hline
\end{tabular}

incubation time over the summer months showed that the average $\mathrm{FDC}\left(t_{1}\right)$ value $($ mean $=18.65, \mathrm{SD}=10.42)$ was significantly higher $(F=8.61, p<0.01)$ than the average $F D C\left(t_{0}\right)$ value (mean $=3.59, \mathrm{SD}=1.21$ ). No significant difference could be detected between $\operatorname{FDC}\left(t_{1}\right)$ and $\operatorname{FDC}\left(t_{0}\right)$ for winter and early spring, indicating a less dynamic population growth during the cold seasons of the year. Although low FDC $\left(t_{1}\right)$ values in winter seemed to be correlated with high doubling times and low doubling times in summer with high FDC $\left(t_{1}\right)$ values, the statistical significance of this trend could not be confirmed by regression analysis. Also, no significant relationship could be detected for the specific growth rates and $\mathrm{FDC}\left(t_{0}\right)$ or $\mathrm{FDC}\left(t_{1}\right)$. Bacterial production rates in summer reached $6.67 \mu \mathrm{g} \mathrm{C} \mathrm{l}^{-1} \mathrm{~h}^{-1}$ (July 1990) with a mean value of $2.03(\mathrm{SD}=2.00$ ), the lowest value being recorded for the middle of August with $0.50 \mu \mathrm{g} \mathrm{Cl}^{-1} \mathrm{~h}^{-1}$. With the exception of the abovementioned high production rate in July 1990, the calculated summer production rates ranged between 0.5 and $2.9 \mu \mathrm{g} \mathrm{C}^{-1} \mathrm{~h}^{-1}$. For January and April 1990 mean bacterial production amounted to $0.76 \mu \mathrm{g} \mathrm{C} \mathrm{I}^{-1}$ $\mathrm{h}^{-1}(\mathrm{SD}=0.76)$, the highest value being $1.72 \mu \mathrm{g} \mathrm{Cl}^{-1}$ $\mathrm{h}^{-1}$, recorded for early spring 1990 . Our estimates of bacterial biomass in the dialysis bags ranged from 8.26 to $47.51 \mu \mathrm{g} \mathrm{C}^{-1}$ for the summer periods and from 8.79 to $17.84 \mu \mathrm{g} \mathrm{C} \mathrm{I}^{-1}$ for winter. We compared the bacterial biomass from $2 \mu \mathrm{m}$ filtered samples with that obtained from unfiltered samples in Fig. 2, which were collected some 12 to $48 \mathrm{~h}$ later. Despite these time intervals, observed differences in biomass could not be confirmed statistically ( $F=3.15, p>0.05)$. This was in agreement with earlier observations on bacterial biomass from $2 \mu \mathrm{m}$ prefiltered and unfiltered water samples from the water column above the meadow (Velimirov \& Walenta-Simon 1992). To compare bacterial secondary production from within the meadow with production values from the water column obtained by the same methodological approach and during the same sampling period (Velimirov \& Walenta-Simon 1992), we expressed hourly production rates of bacteria as percentage of the production. rates for water column bacteria (Table 2). It could be shown that for the summer months bacterial production within the meadow was lower than in the water column, but that values corresponding to 87.8 and $97.7 \%$ for September 1989 and July 1990 respectively could be reached. In April bacterial production within the meadow was higher than in the water above, amounting to $115.9 \%$ of the water column production. However, statistical analysis revealed that no significant difference in the variations of mean production rates within and above the meadow could be detected ( $F=2.24, \mathrm{p}>0.01$ ), leading to the rejection of the hypothesis on differences in production rates for bacteria in the water within the meadow and in the water column on a seasonal basis.

Despite the finding that bacterial production rates within and above the meadow were not different, a tendency, although non-significant, towards lower production rates within the meadow (with the exception of April) was noticed. This observation led us to the question whether the recorded production rates within the meadow are representative estimates or whether they are mainly the result of existing limitations inherent in the method.

Table 2. Bacterial secondary production $\left(\mu \mathrm{g} \mathrm{C} \mathrm{I} \mathrm{I}^{-1} \mathrm{~h}^{-1}\right)$ within the meadow $\left(\mathrm{BSP}_{\mathrm{M}}\right)$ and in the water column (BSP $\mathrm{P}_{\mathrm{W}}$ ) for the investigation periods between July 1989 and 1990. Data are mean values of all incubation experiments. $\mathrm{BSP}_{\mathrm{w}}$ values calculated from Velimirov \& Walenta-Simon (1992)

\begin{tabular}{|lccc|}
\hline Month & BSP $_{M}$ & BSP $_{W}$ & BSP $_{M}[\%$ of BSP \\
\hline Jul 1989 & 2.08 & 5.66 & 36.75 \\
Aug 1989 & 0.66 & 3.69 & 17.89 \\
Sep 1989 & 1.45 & 1.65 & 87.88 \\
Jan 1990 & 0.16 & 0.48 & 33.33 \\
Apr 1990 & 1.38 & 1.19 & 115.97 \\
Jul 1990 & 3.96 & 4.05 & 97.78 \\
\hline
\end{tabular}


The fact that water sampled between the seagrass shoots was $2 \mu \mathrm{m}$ prefiltered and incubated within the meadow could have a number of implications which are not necessarily valid for experiments with prefiltered water sampled and incubated in the water column above the meadow. Filtration removes the particulate fraction above $2 \mu \mathrm{m}$ as well as the attached bacteria on these particles. Because the seagrass meadow is known to act as a sediment trap one may speculate that more POM could be suspended in the water within the meadow than in a similar volume of water above the meadow. This would imply that more bacteria are eliminated when filtering water from within the meadow as compared to water from above, leading to a possible underestimation of bacterial production rates. Furthermore, bacteria on organic aggregates are known to produce intense hydrolytic enzyme activity (Smith et al. 1992) and the elimination of POM by filtration may therefore lead to the elimination of a DOC source for free heterotrophic bacteria. A further point deserving attention is the possibility of a different molecular size spectrum for DOC in the water within the meadow than in the water column. Iturriaga (1981) showed that photosynthetic extracellular products with a molecular weight below 500 were utilized at a faster rate by bacteria than those with a molecular weight above 500 . The diffusion rate across the dialysis membrane for DOC with a molecular weight below 500 , comprising most monomeric carbohydrates and dissolved free amino acids, is expected to be reduced by 40 to $60 \%$ (Schultz \& Gerhard 1969) as compared to the diffusion rate in water. Since the diffusion rate across the dialysis membrane is dependent upon the diameter of the molecules, which can be approximated by the cube root of the molecular weight (Schultz \& Gerhard 1969), the dominance of DOC with a molecular weight above 500 would imply that the permeation of molecules would be more reduced for experiments within the meadow than for the overlying water column. This effect may decrease the total amount of DOC available within $24 \mathrm{~h}$ for bacterial hydrolysis and limit bacterial production rate within the dialysis bags.

We have so far no experimental evidence indicating a higher particle load or a dominance of high molecular weight DOC within the meadow. We can only speculate that the water body is homogeneous from surface to bottom in winter and early spring, with respect to parameters such as particle distribution and DOC molecule size, due to storm-enhanced water movement and reduced shading effect of short seagrass leaves. In January and February 1990 we noticed similar chl a concentrations within the shortened meadow and the overlying water column ranging from 0.35 to $0.37 \mu \mathrm{g} \mathrm{C} \mathrm{l}^{-1}$ (Fig. 3) and 0.28 to $0.35 \mu \mathrm{g} \mathrm{C} \mathrm{l}^{-1}$ respectively (Velimirov \& Walenta-Simon 1992), indi- cating an input of phytoplanktonic carbon from the water column into the seagrass bed. Therefore, we expect similar conditions for bacterial production at both sites from December to early April and consider the obtained rates to be representative estimates. A heterogeneous situation between the sites with respect to POM abundance and the DOC molecular weight spectrum may occur in summer, when mixing processes are slow and probably less frequent. Fig. 3 shows that for the rest of the year phytoplanktonic carbon was low, with chl a concentrations ranging from 0.01 to $0.06 \mu \mathrm{g} \mathrm{I}^{-1}$, contrasting with concentrations in the overlying water column which ranged from 0.02 to $0.24 \mu \mathrm{g} \mathrm{l}^{-1}$ (Velimirov \& Walenta-Simon 1992). We performed only a limited number of incubation experiments to monitor $\mathrm{O}_{2}$ production and consumption within the meadow over the summer period (Table 3 ). As expected, $\mathrm{O}_{2}$ production was lower than for the water column above the meadow in the same month (Velimirov \& Walenta-Simon 1992). For the 3 summer experiments respiration in the dark flasks was higher than net primary production in light flasks, which was not observed for the 2 winter experiments, showing that the zooplankton and bacterioplankton community in the water within the meadow respires up to $70 \%$ of the phytoplanktonic gross primary production in summer. The above information may be an indication that in summer less phytoplanktonic extracellular products are available in the water within the seagrass system than above the meadow, but at present the available data do not allow us to decide whether bacteria within the meadow are subject to specific nutrient conditions in summer which limit the experimental approach. However, one can speculate about the importance of transfer processes from different carbon sources to cover bacterial carbon requirements by using available data on the transferred substances, even though no measurements on rates of water exchange or diffusion have been published for seagrass meadows in general. Two additional sources of carbon to be considered are the leaching of soluble

Table 3. Mean oxygen production and consumption in the waterlayer within the meadow. NPP: oxygen evolution in light bottles; RESP: oxygen evolution in dark bottles. All values in $\mu \mathrm{g} \mathrm{O}_{2} \mathrm{l}^{-1} \mathrm{~h}^{-1} ; \mathrm{n}=$ number of light and dark bottles per experiment

\begin{tabular}{|cccrrrrrr|}
\hline $\begin{array}{l}\text { Date } \\
(1990)\end{array}$ & $\begin{array}{c}\text { Incubation } \\
(\mathrm{h})\end{array}$ & $\mathrm{n}$ & \multicolumn{2}{c}{ NPP } & $\mathrm{n}$ & \multicolumn{2}{c|}{ RESP } \\
\hline Mean & $\mathrm{SD}$ & & & \\
Mean & $\mathrm{Jan}$ & 4.5 & 3 & 7.13 & 2.80 & 3 & 6.80 & 1.31 \\
$2 \mathrm{Feb}$ & 4 & 3 & 10.02 & 3.14 & 3 & 7.90 & 2.77 \\
$17 \mathrm{Jul}$ & 6 & 2 & 7.26 & 2.28 & 2 & 9.36 & 3.50 \\
$22 \mathrm{Jul}$ & 4 & 3 & 4.93 & 3.00 & 3 & 11.52 & 2.90 \\
$29 \mathrm{Jul}$ & 6 & 3 & 6.93 & 3.48 & 4 & 10.42 & 3.19 \\
\hline
\end{tabular}


compounds from Posidonia oceanica leaves plus associated epiphytes, and the degradation products of shed and torn-off leaves or leaf particles on the sediment and from the wrack bed within the meadow.

In Table 4 we list the averaged biomass and production values obtained from the present study with the available information on carbon release rates from previous investigations. We have no data on DOC release for our specific seagrass site in the Bay of Calvi, but limited information on the release of free amino acids from the sediment to the overlying water is available from Jørgensen et al. (1981). Using sediment cores from $8 \mathrm{~m}$ depth in laboratory experiments, a net transfer rate of amino acids into the water, corresponding to $10.56 \mathrm{mg}$ $\mathrm{C} \mathrm{m}^{-2} \mathrm{~d}^{-1}$, was determined. Data from leaching experiments on Posidonia oceanica as well as on total DOC release from the sediment/wrack compartment (Velimirov 1986, 1987) are available for a $20 \mathrm{~m}$ deep site from Lacco Ameno (Island of Ischia, off Naples, Italy). Ledching from $P$. oceanica plus epiphytes was estimated to amount to $84.48 \mathrm{mg} \mathrm{C} \mathrm{m}{ }^{-2} \mathrm{~d}^{-1}$, while the DOC release from sediment plus wrack, monitored in bell jar experiments over $24 \mathrm{~h}$ from April to July, averaged $13.64 \mathrm{~g} \mathrm{C}$ $\mathrm{m}^{-2} \mathrm{~d}^{-1}$. In our dialysis bag experiments bacterial production is mainly based on degradation and uptake of dissolved organic substances rather than decomposition of particles over $24 \mathrm{~h}$. Choosing therefore a carbon conversion efficiency of $50 \%$ obtained from studies using

Table 4. Comparison of averaged values and ranges for heterotrophic bacteria biomass (HBB), bacterial secondary production (BSP) and phytoplankton primary production $\left(\mathrm{PP}_{\text {Phyto }}\right)$ in the water layer within the meadow for periods of high $\left(>16^{\circ} \mathrm{C}\right)$ and low $\left(<16^{\circ} \mathrm{C}\right)$ temperature regimes over a year

\begin{tabular}{|c|c|c|}
\hline & $\begin{array}{c}\text { May-October } \\
\left(\text { Temperature }>16^{\circ} \mathrm{C}\right)\end{array}$ & $\begin{array}{c}\text { November-April } \\
\left(\text { Temperature }<16^{\circ} \mathrm{C} \text { ) }\right.\end{array}$ \\
\hline $\mathrm{HBB}\left(\mathrm{mg} \mathrm{C} \mathrm{m} \mathrm{m}^{-3}\right.$ ) & $\begin{array}{c}26.9 \\
(6.8-81.6)\end{array}$ & $\begin{array}{c}20.6 \\
(6.8-30.6)\end{array}$ \\
\hline $\mathrm{BSP}\left(\mathrm{mg} \mathrm{C} \mathrm{m}^{-3} \mathrm{~d}^{-1}\right)$ & $\begin{array}{c}48.9 \\
(12.0-160.0)\end{array}$ & $\begin{array}{c}18.4 \\
(0.4-41.2)\end{array}$ \\
\hline $\mathrm{PP}_{\text {Phyto }}\left(\mathrm{mg} \mathrm{C} \mathrm{m} \mathrm{m}^{-3} \mathrm{~d}^{-1}\right)^{\mathrm{a}}$ & $\begin{array}{c}85.6 \\
(81.2-89.1)\end{array}$ & 79.9 \\
\hline \multicolumn{3}{|c|}{ Carbon release (mg C m${ }^{-2} \mathrm{~d}^{-1}$ ) } \\
\hline \multicolumn{2}{|c|}{$\begin{array}{l}\text { P. oceanica + epiphytes }{ }^{b} \text { (DOC) } \\
\text { Sediment }+ \text { wrack }^{\mathrm{b}} \text { (DOC) } \\
\text { Sediment }{ }^{\mathrm{c}} \text { (DOC calculated from DFAA) }\end{array}$} & $\begin{array}{c}84.4 \\
13641.6 \\
10.5\end{array}$ \\
\hline \multicolumn{3}{|c|}{$\begin{array}{l}\text { "We estimated daily primary productivity in the water layer within the } \\
\text { meadow by assuming that the rates measured over the incubation } \\
\text { intervals (Table 3) are representative for the photoperiod of the day } \\
\text { (Murray \& Wetzel 1987), defined as } 90 \% \text { of daylight hours (winter: } 8.53 \mathrm{~h} \text {, } \\
\text { summer: } 12.44 \mathrm{~h} \text {, meteorological station airport St. Cathrine/Calvi) }\end{array}$} \\
\hline \multicolumn{3}{|c|}{${ }^{b}$ Data from Velimirov (1986) } \\
\hline \multicolumn{3}{|c|}{$\begin{array}{l}\text { 'Data from Jørgensen et al. (1981) assuming a mean molecular weight of } \\
110 \text { and a carbon content of } 38.98 \% \text { for dissolved free amino acids } \\
\text { (DFAA) from Velimirov (1986) }\end{array}$} \\
\hline
\end{tabular}

low molecular weight substrates (Ituriaga \& Hoppe 1977, Billen et al. 1980, Iturriaga \& Zsolnay 1981) rather than the recommended $20 \%$ conversion efficiency resulting from experiments using natural detritus (Linley \& Newell 1984, Bjornsen 1986) in long-term experiments, some $97.92 \mathrm{mg} \mathrm{C} \mathrm{m}^{-3} \mathrm{~d}^{-1}$ would be required to support the bacterial summer production and $36.96 \mathrm{mg}$ $\mathrm{C} \mathrm{m}^{-3} \mathrm{~d}^{-1}$ for the winter production. From Table 4 it can be seen that theoretically the summer phytoplanktonic primary production could support up to $87 \%$ of the bacterial summer production, while phytoplanktonic winter production could support twice the bacterial winter production. Assuming that only half of the phytoplankton production is available to heterotrophic bacteria and the rest is consumed by zooplankton, some additional $55.1 \mathrm{mg}$ of carbon would have to come from the seagrass system in summer. A total DOC release rate from seagrass leaves, epiphytes and the sediment with the rhizomes and its detritus fraction of $13726 \mathrm{mg} \mathrm{C} \mathrm{m}^{-\hat{2}} \mathrm{~d}^{-1}$ can take place from April to July. Even though one has to expect that the main fraction of this DOC consists of high molecular weight compounds and that only a small fraction represents easily degradable DOC, one may speculate that all of the bacterial secondary production can be supplied by the seagrass system assuming that only $1 \%$ of the daily release rate per $\mathrm{m}^{2}$ seagrass bed is present as carbon from dissolved free amino acids (DFAA) and dissolved monosaccharides (MCHO). The corresponding $137 \mathrm{mg} \mathrm{C} \mathrm{m} \mathrm{m}^{-2} \mathrm{~d}^{-1}$ could cover the bacterial carbon requirements alone to support the total summer production within the meadow and some remaining $39 \mathrm{mg} \mathrm{C} \mathrm{m} \mathrm{m}^{-2} \mathrm{~d}^{-1}$ could be channeled into the bacterial production of the water column above the meadow. Adding to this value $42.8 \mathrm{mg} \mathrm{C}$, which is one half of the phytoplankton production, a total of $81.8 \mathrm{mg}$ $\mathrm{C} \mathrm{m}^{-2} \mathrm{~d}^{-1}$ is available for further use. We assume therefore that the higher bacterial production values in summer are the result of both higher temperatures enhancing metabolic processes and an overabundance of utilizable dissolved organic carbon. Consequently both low and high molecular weight DOC could be made available to the bacteria above the meadow via processes like upwards diffusion or slow water exchange between meadow and the water column. This would be an indication that over the summer period the bacteria in the water column above the meadow may tap easily utilizable carbon from the seagrass system in addition to the carbon originating from phytoplankton production. 
The amount of DOC corresponding to the proportion of DFAA and MCHO in the water above and within a Posidonia oceanica meadow (Velimirov 1986) was shown to range from 0.8 to $3.7 \%$ of the total DOC for a $15 \mathrm{~m}$ and a $20 \mathrm{~m}$ station which is in agreement with findings from Mopper et al. (1980) and Bölter (1981). As DFAA and MCHO fractions are utilized at varying rates by the microheterotrophs over the day, the concentration of the utilizable fraction within the measured DOC reflects the amount of easily degradable material which is still available for consumption. The above carbon balance estimations and the findings on the concentration magnitude of DFAA and $\mathrm{MCHO}$ within and above the seagrass meadow of previous studies (Jørgensen et al. 1981, Velimirov 1986) may be seen as an indication that the low molecular weight compounds within the DOC are not limiting factors for bacterial growth in our system.

Acknowledgements. This work was supported by the Fonds zur Förderung der wissenschaftlichen Forschung Projekt Nr. P 6559 B. We thank the staff of STARESO SA. for boat and diving assistance and 4 anonymous referees for constructive comments on the first version of the manuscript.

\section{LITERATURE CITED}

Bender, M., Grande, K., Johnson, K., Marra, J., Williams, P. J. leB., Sieburth, J., Pilson, M., Langdon, C., Hitchcock, G., Orchado, J., Hunt, C., Donaghay, P., Heinemann, K. (1987). A comparison of four methods for determining planktonic community production. Limnol. Oceanogr. 32 1085-1098

Billen, G., Joiris, C., Wijnant, J., Gillian, G. (1980). Concentrations and microbiological utilization of small organic molecules in Scheldt. Estuary, the Belgian Coastal zone and the English Channel. Estuar. coast. mar. Sci. 11 279-294

Bjørnsen, P. K. (1986). Bacterioplankton growth yield in continuous seawater cultures. Mar. Ecol. Prog. Ser. 30: $191-196$

Bölter, M. (1981). DoC-turnover and microbial biomass production. Kieler Meeresforsch., Sonderh. 5: 304-310

Hagström, A., Larsson, U., Horstedt, P., Normark, S. (1979). Frequency of dividing cells, a new approach to the determination of bacterial growth rates in aquatic environments. Appl. environ. Microbiol. 37: 805-812

Harmelin, J. G. (1964). Etude de l'endofaune des 'mattes' d'herbier de Posidonia oceanica Delile. Recl Trav. Stn mar. Endoume 35: 43-106

Hobbie, J. E., Daley, R. J., Jasper, S. (1977). Use of nuclepore filters for counting bacteria by fluorescence microscopy. Appl. environ. Microbiol. 33: 1225-1228

Holligan, P. M., Williams, P. J. leB., Purdie, D., Harris, R. P. (1984). Photosynthesis, respiration and nitrogen supply

This article was presented by G. Rheinheimer, Kiel Germany of plankton populations in stratified, frontal and tidally mixed shelf waters. Mar. Ecol. Prog. Ser. 17: 201-213

Iturriaga, R. (1981). Phytoplankton photoassimilated extracellular products; heterotrophic utilization in marine environment. Kieler Meeresforsch., Sonderh. 5: 318-324

Iturriaga, R., Hoppe, H.-G. (1977). Observations of heterotrophic activity on photoassimilated matter. Mar Biol. 40: $101-108$

Iturriaga, R., Zsolnay, A. (1981). Transformation of some dissolved organic compounds by a natural heterotrophic population. Mar. Biol. 62: 125-129

Jorgensen, N. O. G., Blackburn, T. H., Henriksen, K., Bay, D. (1981). The importance of Posidonia oceanica and Cymodocea nodosa as contributors of free amino acids in water and sediment of seagrass beds. P.S.Z.N. I: Mar. Ecol. 2: $97-112$

Ledoyer, M. (1966). Ecologie de la faune vagile des biotopes méditerranéens accessibles en scaphandre autonome Recl Trav. Stn mar. Endoume 41: 135-186

Lee, S., Fuhrman, J. A. (1987). Relationships between biovolume and biomass of naturally derived marine bacterioplankton. Appl. environ. Microbiol. 53: 1298-1303

Linley, E. A. S., Newell, R. C. (1984). Estimates of bacterial growth yields based on plant detritus. Bull. mar. Sci. 35: 409-425

Mopper, K., Ittekot, V., Dawson, R., Liebezeit, G. (1980). The monosaccharide spectra of natural waters. Mar. Chem 10: $55-66$

Murray, L., Wetzel, L. R. (1987). Oxygen production and consumption associated with the major autotrophic components in two temperate seagrass communities. Mar. Ecol Prog. Ser. 38: 231-239

Parsons, T R., Maita, Y., Lalli, C. M. (1985). A manual of chemical and biological methods for seawater analysis. Pergamon Press, Oxford, p. 173

Schultz, J. S., Gerhardt, P. (1969). Dialysis culture of microorganisms: design, theory and results. Bact. Rev. 33: 1-47

Smith, D. C., Simon, M., Alldredge, A. L., Azam, F. (1992) Intense hydrolytic enzyme activity on marine aggregates and implications for rapid particle dissolution. Nature 359: $139-142$

Turley, C. M., Lochte, K. (1985). Direct measurement of bacterial productivity in stratified waters close to a front in the Irish Sea. Mar. Ecol. Prog. Ser. 23: 209-219

Velimirov, B. (1986). DOC dynamics in a Mediterranean seagrass system. Mar. Ecol. Prog. Ser. 28: 21-41

Velimirov, B. (1987). Organic matter derived from a seagrass meadow: origin, properties and quality of particles. P.S.Z.N. I: Mar. Ecol. 8: 143-173

Velimirov, B., Ott, J. A., Novak, R. (1981). Microorganisms on macrophyte debris: biodegradation and its implication in the food web. Kieler Meeresforsch., Sonderh. 5: $333-344$

Velimirov, B., Walenta-Simon, M. (1992). Seasonal changes in specific growth rates, production and biomass of a bacterial community in the water column above a Mediterranean seagrass system. Mar. Ecol. Prog. Ser. 80: $237-248$

Williams, P. J. leB., Robertson, J. E. (1991). Overall planktonic oxygen and carbon dioxide metabolisms: the problem of reconciling observations and calculations of photosynthetic quotients. J. Plankton Res. 13: 153-169

Manuscript first received: July 3, 1992

Revised version accepted: March 3, 1993 